\title{
Neurocutaneous melanosis in a newborn identified prenatally by non-invasive imaging
}

\author{
Melanoza nerwowo-skórna u noworodka stwierdzona prenatalnie badaniami \\ obrazowymi
}

\author{
Hubert Huras', Joanna Hurkała², Małgorzata Radoń-Pokracka', Grzegorz Dyduch³, \\ Anna Taczanowska-Niemczuk ${ }^{4}$, Robert Jach ${ }^{5}$, Jakub Droś6, Ryszard Lauterbach ${ }^{2}$
}

\begin{abstract}
'Department of Obstetrics and Perinatology, Jagiellonian University Medical College, Krakow, Poland 2Department of Neonatology, Jagiellonian University Medical College, Krakow, Poland

3Department of Pathomorphology, Jagiellonian University Medical College, Krakow, Poland

${ }^{4}$ Department of Pediatric Surgery, Jagiellonian University Medical College, Krakow, University Children's Hospital, Poland

${ }^{5}$ Department of Gynecological Endocrinology, Jagiellonian University Medical College, Krakow, Poland

${ }^{6}$ Perinatology Students' Scientific Group, Department of Obstetrics and Perinatology, Jagiellonian University Medical College, Krakow, Poland

'Klinika Położnictwa i Perinatologii Uniwersytetu Jagiellońskiego Collegium Medicum w Krakowie, Polska

${ }^{2}$ Klinika Neonatologii Uniwersytetu Jagiellońskiego Collegium Medicum w Krakowie, Polska

${ }^{3}$ Katedra Patomorfologii Uniwersytetu Jagiellońskiego Collegium Medicum w Krakowie, Polska

${ }^{4}$ Klinika Chirurgii Dziecięcej Uniwersytetu Jagiellońskiego Collegium Medicum w Krakowie, Uniwersytecki Szpital Dziecięcy, Polska

${ }^{5}$ Klinika Endokrynologii Ginekologicznej Uniwersytetu Jagiellońskiego Collegium Medicum w Krakowie, Polska

${ }^{6}$ Studenckie Koło Perinatologiczne, Klinika Położnictwa i Perinatologii Uniwersytetu Jagiellońskiego Collegium Medicum w Krakowie, Polska
\end{abstract}

A 21-year-old pregnant woman (gravida 1 para 1) was referred to the Department of Obstetrics and Perinatology for sonographic examination, which revealed a fetus at $29+6$ weeks with an irregular cystic-solid subcutaneous mass of heterogeneous echogenicity $(16 \times 10 \times 9 \mathrm{~cm}$ in size $)$ covering the surface of both shoulders and the dorsal chest wall (fig. 1). No increase in tumor size was detected up to the delivery.

The neonate was a boy, born in good condition by cesarean section after 39 weeks of gestation. At birth, he was found to have multiple congenital melanocytic nevi. An extensive nevus was noted on the trunk, covering the thorax, loins, buttocks and both thighs, having a circumferential distribution. It was hairy and partially composed of large, elevated tubers (figs. 2, 3).

Because of the suspicion of neurocutaneous melanosis (NCM), the newborn was given an magnetic resonance imaging (MRI) examination which showed the presence of multiple hiperintense lesions, from 3 to $6 \mathrm{~mm}$ in diameter, in the cerebellum, medulla oblongata, the enteral part of the pons, left thalamus, calcarine sulcus, and in the parietal-occipital sulcus. Skin biopsy revealed a melanocytic proliferation
Dwudziestojednoletnia kobieta w ciąży (ciąża 1., poród 1.) została skierowana do Katedry Ginekologii i Położnictwa w celu wykonania badania ultrasonograficznego, w którym stwierdzono płód w 29. tygodniu i 6. dniu z nieregularną, lito-torbielowatą masą podskórną o heterogenicznej echogeniczności (16 × $10 \times 9 \mathrm{~cm}$ ) na powierzchni obu ramion obejmującą część grzbietową tułowia (ryc. 1). Rozmiary guza nie zwiększyły się do porodu.

Chłopiec urodził się przez cesarskie cięcie po 39. tygodniu ciąży w stanie dobrym. U noworodka obecne były mnogie wrodzone znamiona barwnikowe. Obserwowano rozległe znamię rozmieszczone obwodowo, obejmujące tułów, okolicę lędźwiową, pośladki i oba uda. Znamię było owłosione i częściowo złożone z dużych, uniesionych guzów (ryc. 2, 3).

$\mathrm{Z}$ powodu podejrzenia melanozy nerwowo-skórnej (neurocutaneous melanosis - NCM) noworodek został poddany badaniu rezonansem magnetycznym ( $m a-$ gnetic resonance imaging - MRI), w którym stwierdzono liczne hiperintensywne zmiany o średnicy 3-6 mm w móżdżku, rdzeniu przedłużonym, brzusznej części mostu, lewym wzgórzu, bruździe ostrogowej i w bruździe ciemieniowo-potylicznej. Biopsja skóry 
suggestive of proliferative neurocristic hamartoma as a variant of a congenital melanocytic nevus (figs. $4,5)$. In the first dermatoscopy, the features of malignancy were excluded.

In his $22^{\text {nd }}$ month of life, the infant was neurologically asymptomatic, with no signs of epilepsy and generally correct development. A subsequent MRI with contrast revealed mild enlargement of the third and fourth brain ventricles, partial hypoplasia of the lower part of the vermis, other hiperintense lesions in the cortical area, as well as meningeal involvement.

Neurocutaneous melanosis is a rare congenital disorder with a frequency of 1 in 20,000 live births, which is probably caused by improper migration of neural crest cells [1]. Diagnosis of NCM is based on the presence of giant inborn melanocytic nevus (larger than $20 \mathrm{~cm}$ for adults and 6-9 $\mathrm{cm}$ diameter for newborn patients), or numerous smaller melanocytic lesions accompanied by melanocytic tumors in the central nervous system (CNS). Symptomatic patients (presenting seizures, hydrocephaly or high intracra- wykazała proliferację melanocytów z komórek grzebienia nerwowego, która świadczyła o rozrostowym guzie - hamartoma, będącym wariantem wrodzonego znamienia barwnikowego (ryc. 4, 5). Pierwsza dermatoskopia wykluczyła cechy złośliwości.

U niemowlęcia w 22. miesiącu życia nie stwierdzono zaburzeń neurologicznych, w tym padaczki, a jego rozwój oceniono jako prawidłowy. Dalsze obrazowanie metodą MRI wykazało niewielkie powiększenie komory trzeciej i czwartej, częściową hipoplazję dolnej części robaka móżdżku, inne hiperintensywne zmiany w częściach kory oraz zajęcie opon mózgowo-rdzeniowych.

Melanoza nerwowo-skórna to rzadka choroba wrodzona, która występuje z częstością 1 na 20000 żywych porodów i jest najprawdopodobniej wywoływana przez nieprawidłową migrację komórek grzebienia nerwowego [1]. Diagnoza opiera się na występowaniu olbrzymiego wrodzonego znamienia melanocytowego (o średnicy większej niż $20 \mathrm{~cm}$ u dorosłych i 6-9 cm u noworodków) lub licznych mniej-
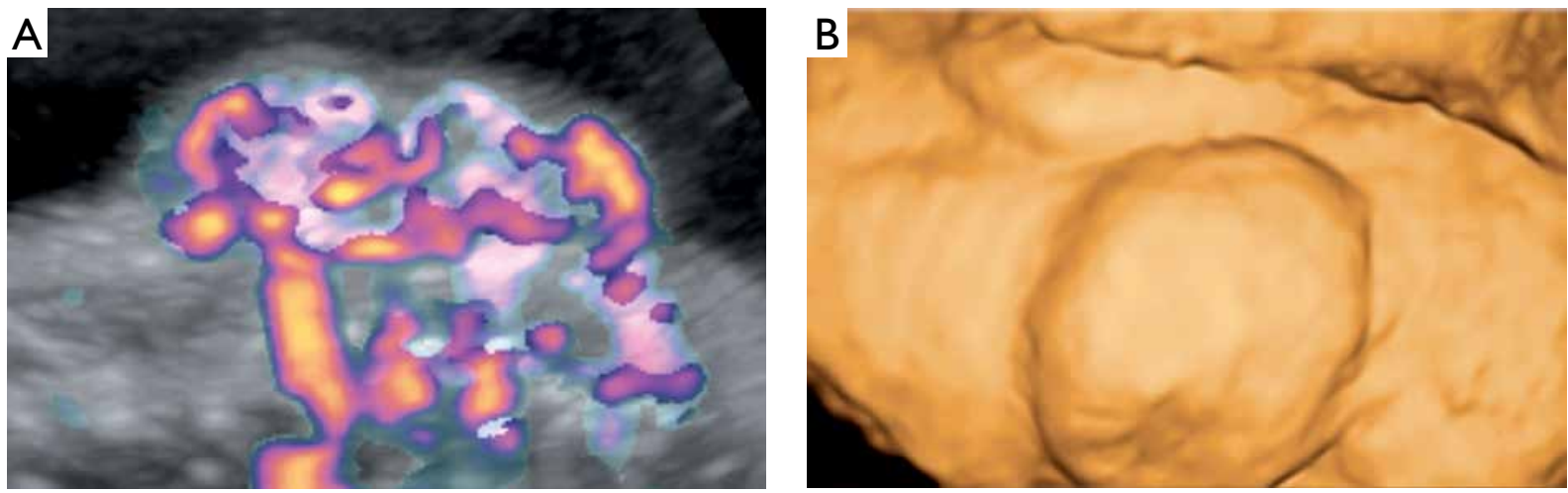

Figure I. An unknown mass on the fetal trunk in sonographic examination: intense and chaotic low resistance vascularization (RI 0.48) presented in Color Doppler imaging (A); three-dimensional surface rendering showed an irregular and nodular tumor surface (B)

Rycina I. Nieznana masa na tułowiu płodu w obrazie ultrasonograficznym: intensywne i chaotyczne niskooporowe unaczynienie (RI 0,48) w badaniu USG Doppler (A); trójwymiarowe obrazowanie wykazało nieregularną i guzowatą powierzchnię guza (B)

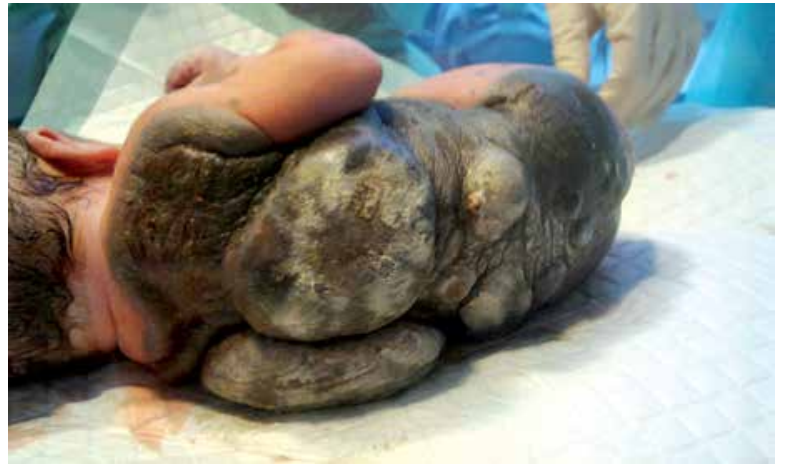

Figure 2. Giant melanocytic nevus in the newborn's trunk partially composed of the large elevated tubers

Rycina 2. Olbrzymie znamię melanocytowe na tułowiu noworodka częściowo składające się z dużych wyniesionych guzów

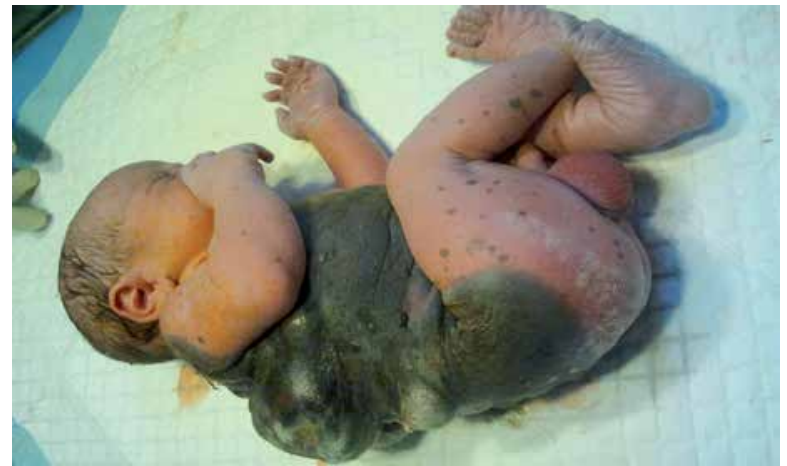

Figure 3. Giant nevus covering thorax, loins, buttocks and both thighs with numerous melanocytic nevi located on the extremities and scalp

Rycina 3. Olbrzymie znamię pokrywające tułów, okolicę lędźwiową, pośladki oraz oba uda wraz z licznymi znamionami melanocytowymi zlokalizowanymi na kończynach i skórze głowy 


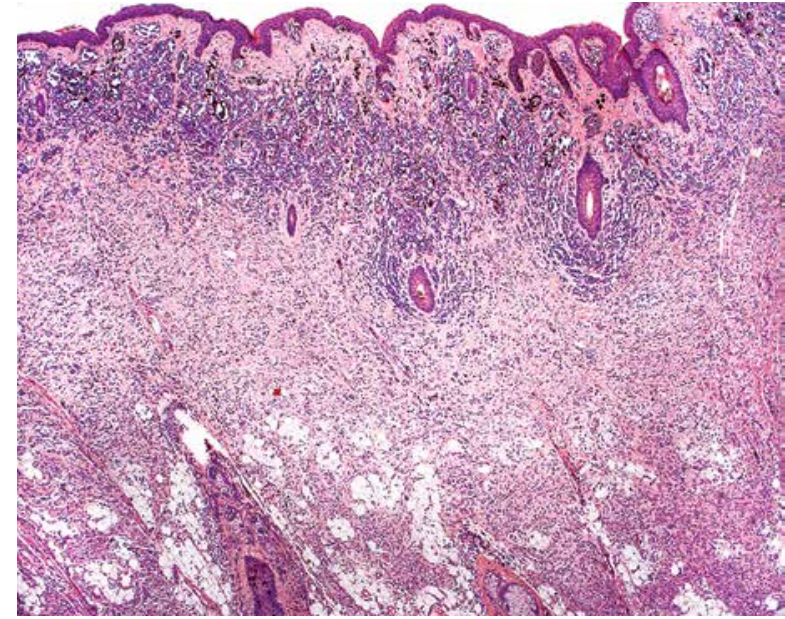

Figure 4. Histopathological examination: melanocytic proliferation involving dermis and subcutis with an apparent junctional component

Rycina 4. Badanie histopatologiczne: proliferacja melanocytowa obejmująca skórę właściwą i tkankę podskórną z pozorną składową łączącą

nial pressure), have an enhanced - often fatal - prognosis [2].

The spread of benign or malignant pigment cell tumors of the leptomeninges is observed in NCM, and this determinates the prognosis. Leptomeninges should be assessed after MRI with contrast, and examinations should be repeated as there is a high risk of melanoma. Overall, the reported risk of malignant melanoma for NCM in the CNS is 50\% [3].

At present, there is no specific therapy for NCM. The prognosis is poor, with most patients dying 1 year after the first neurologic symptoms [2]. However, some authors have reported an absence of neurological deterioration, even with leptomeningeal involvement in NCM [4].

Our patient is one of the youngest reported in the literature, and his early diagnosis is uncommon - other authors have reported confirmed NCM 2 days after birth, or in 2-month-old infants [5]. Interestingly, in our patient the first non-specific symptoms appeared in an ultrasound examination performed at the fetal life.

\section{CONFLICT OF INTEREST}

The authors declare no conflict of interest.

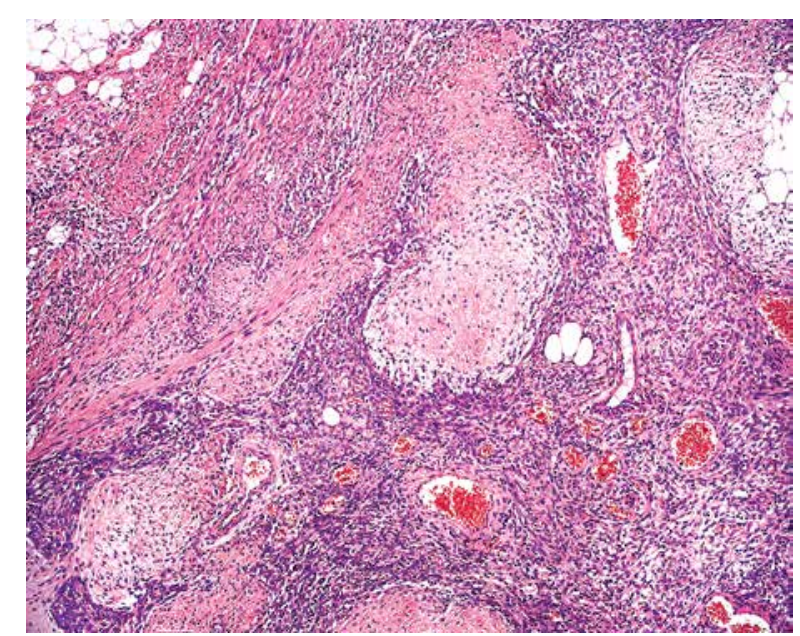

Figure 5. Histopathological examination: epithelioid and spindle melanocytes constituting deep component with loose myxoid areas and foci of neural differentiation

Rycina 5. Badanie histopatologiczne: melanocyty nabłonkowe i wrzecionowe stanowiące głęboki element z luźnymi obszarami śluzowymi i ogniskami zróżnicowania nerwowego

szych zmian melanocytowych, którym towarzyszą melanocytowe guzy w ośrodkowym układzie nerwowym (OUN). Rokowanie u pacjentów, u których występują objawy (napady drgawkowe, wodogłowie lub nadciśnienie wewnątrzczaszkowe), jest często złe, gdyż choroba jest potencjalnie śmiertelna [2].

W NCM obserwuje się rozplem nowotworowych komórek barwnikowych, niezłośliwych lub złośliwych, w oponach miękkich, co wpływa na rokowanie. Opony miękkie należy poddać ocenie po badaniu metodą MRI z zastosowaniem środka kontrastowego, a badanie należy powtarzać z powodu dużego ryzyka wystąpienia czerniaka. Ogólnie ryzyko rozwoju czerniaka złośliwego w NCM w OUN wynosi 50\% [3].

Obecnie nie istnieje ukierunkowane leczenie NCM. Rokowanie jest bardzo złe, a większość pacjentów umiera rok po wystąpieniu pierwszych objawów neurologicznych [2]. Część autorów nie stwierdziła jednak pogorszenia stanu neurologicznego pacjentów, nawet gdy zajęte były opony miękkie [4].

Przedstawiony pacjent należy do najmłodszych opisanych w piśmiennictwie, a tak wczesne rozpoznanie jest rzadkie - inni autorzy opisują potwierdzenie NCM 2 dni po urodzeniu lub u 2-miesięcznego niemowlęcia [5]. Na szczególną uwagę zasługuje fakt, że $\mathrm{u}$ zaprezentowanego pacjenta pierwsze objawy nieswoiste wykazano w badaniu ultrasonograficznym w okresie życia płodowego.

\section{KONFLIKT INTERESÓW}

Autorzy nie zgłaszają konfliktu interesów. 


\section{References}

\section{Piśmiennictwo}

1. Chu W., Lee V., Chan Y., Shing M., Chik K., Li C., et al.: Neurocutaneous melanomatosis with a rapidly deteriorating course. AJNR Am J Neuroradiol 2003, 24, 287-290.

2. Kadonaga J.N., Frieden I.J.: Neurocutaneous melanosis: definition and review of the literature. J Am Acad Dermatol 1991, $24,747-755$

3. Krengel S., Hauschild A., Schafer T.: Melanoma risk in congenital melanocytic naevi: a systematic review. Br J Dermatol 2006, 155, 1-8

4. Agero A.L., Benvenuto-Andrade C., Dusza S.W., Halpern A.C., Marghoob A.A.: Asymptomatic neurocutaneous melanocytosis in patients with large congenital melanocytic nevi: a study of cases from an Internet-based registry. J Am Acad Dermatol 2005, 53, 959-965.

5. D’Argenio A., David P., Engohan C., Hennequin Y., Balériaux D., Jissendi P.: Neurocutaneous melanosis in a newborn with giant congenital melanocytic nevus. J Neuroradiol 2007, 34, 272-275.

Received: 3.01 .2018

Accepted: 22.07 .2018

Otrzymano: 3.01.2018 r.

Zaakceptowano: $22.07 .2018 \mathrm{r}$.

How to cite this article

Huras H., Hurkała J., Radoń-Pokracka M., Dyduch G., Taczanowska-Niemczuk A., Jach R., Droś J., Lauterbach R.: Neurocutaneous melanosis in a newborn identified prenatally by non-invasive imaging. Dermatol Rev/Przegl Dermatol 2018, 105, 558-561. DOI: https://doi.org/10.5114/dr.2018.78078. 